\title{
Természeti rekreációs tevékenységek
}

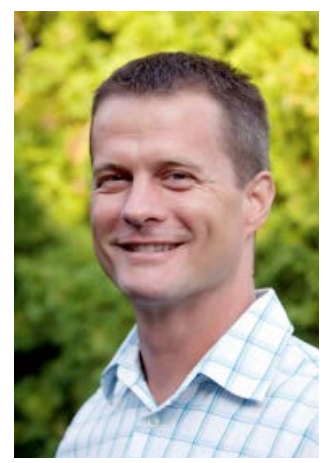

Szerző: DR. FRITZ PÉTER

Titulusa: föiskolai docens

Munkahelye: rekreációszervező és

egészségfejlesztő szak szakfelelős

Eszterházy Károly Főiskola

Sporttudományi Intézet, Eger

e-mail: pfritz@hotmail.hu

Fotó: DR. FRITZ PÉTER, CSIHA

YVETTE

A környezet az élő szervezeteket körülvevő élő és élettelen fizikai, kémiai és biológiai tényezők összessége, a természet egy kis darabja. Az emberi felfogás szerint az a tér vagy terület, ahol emberek közössége él, és olyan mértékben átalakítja, hogy életfeltételeit, igényeit biztosítani tudja. A környezetet szokás felosztani a talaj, víz, levegő, élővilág, táj és épített környezetre is. Mivel az ember ezt ismeri, és élete folyamán ez veszi körül, ezért helyezi előtérbe a természettel szemben (Cseresznye, 2014).

Talán azért is gondoltam ezt a számomra nagyon közeli fejezetet a környezet meghatározásával kezdeni, mert jól láthatók az emberek egyre inkább beszűkült mindennapjai a természet kínálta lehetőségekhez képest. Sokszor tapasztaltam nagyvárosokban, hogy ha valamit kerestem és egy járókelőt megkérdeztem, az szinte kikérve magyarázta, hogy az nem az ő lakókerületében vagy környékén van, ezért hogyan is tudhatná... A környezetünk ismerete is leginkább a napi tevékenységeink ellátásához feltétlen szükséges információmennyiséget jelenti, ezalatt egyaránt értem pl. a megszokott úti terveket, valamint a szokásos utazás során megfigyelt eseményeket, ingereket. Az utazás során az idő, a gyorsaság a szempont, nem pedig a körülöttünk lévő környezet és annak minősége.

De mi van a szabadidőnkkel? Itt visszautalnék a szabadidő meghatározására, ahol a munkába járást, a kötelezettségekkel járó utazást, (pl. gyereket viszem az iskolába, edzésre, vagy rohanok a postára a csekkel) egyértelmüen a félszabadidős tevékenységekhez soroljuk. Sajnos azonban a maradék szabadidőnkben sem fordítunk kellő hangsúlyt környezetünk és tágabb értelemben a természet csodálására, a természettel való együttlétre. Pedig ezen nagyon könnyü változtatni, csak tudatossá kell tegyük magunkban, hogy mi is a természet része vagyunk, bár egyértelműen látszik, hogy az emberiség célja inkább a természet leigázása, kiszipolyozása.

Közvetlen környezetünket alakítsuk úgy, hogy harmóniát sugározzon! Fontos, hogy a lakásunkban kapjanak helyet a növények. Tegyünk környezetünk védelméért, egyrészt tudatos vásárlással, fogyasztói szokások átgondolásával, megfelelő környezettudatos mintamutatással.

Ha edzésre rohanunk is, figyelhetünk környezetünkre és a természet üzeneteire, föleg, ha azt nem autóval vagy tömegközlekedéssel tesszük, hanem kerékpárral vagy gyalog.

A természet definíciójának értelmezésekor és rekreációhoz füződő viszonyának elemzésekor ki kell térnünk egy másik kapcsolódó fogalom, az emberi természet bemutatására.

Az emberi természet fogalmának a bölcselet történetében számos megközelítése létezik. Arisztotelész, Spinoza, Kant, Hegel, Marx egyaránt használta ezt a fogalmat, de más-más jelentéstartalom-

\author{
„Ha igazán szereted a természetet, mindenhol megtalálod a \\ szépséget." Vincent Van Gogh
}

mal. Az egyes filozófusok eltérő fogalomhasználata alapján az emberi természet alatt nem ugyanarra a dologra gondolunk. A jelzett fogalom használata számos kérdést vet fel. „A »természethez« tartozik-e az ész vagy nem? Vajon a »természet« minden velünk született emberi hajlamot magába foglal-e, s ezenkívül semmi egyebet? Csak bizonyos velünk született hajlamokat foglal magába, és semmi mást, vagy velünk született és szerzett hajlamokat egyaránt? (...) Miféle szerzett hajlamok tartoznak az emberi természethez?" Ehhez hasonló kérdések sokaságát fogalmazza meg - a probléma kapcsán - Heller Ágnes. A jelzett fogalom jelentése ráadásul egyazon filozófián belül is eltolódhat vagy terjedelmében változhat. Az „emberi természet” és az etika közvetlen viszonyát vizsgálva négy logikai lehetőség kínálkozik, amelyek mindegyikére születtek variációk az idők folyamán. Az első lehetőség szerint az emberi természet alapvetően rossz, természetünk ellenére vagyunk jók. $A$ második lehetőség szerint az emberi természet eredetileg jó, természetünkkel összhangban vagyunk jók. A harmadik lehetőség szerint az emberi természet erkölcsileg közömbös, amely jóvá és rosszá is válhat. A negyedik lehetőség szerint az emberi természetben jó hajlamok éppúgy vannak, mint rosszak, gátló és ösztönző tényezők hatására vagyunk jók vagy rosszak. A logikai lehetőségek tárháza azt jelzi, hogy az erkölcs tisztán racionális magyarázata számbeli kisebbségben van. Így például csak a szókratészi tan nevezhető ésszerünek, hiszen e tan szerint akik ismerik a jót, azok jóvá is válnak. A második, a harmadik és a negyedik megoldás ugyanakkor tartalmazza az erkölcs megjavításának racionális lehetőségét. További probléma az emberi természet fogalmával az, hogy a fogalom maga elsődlegesen ontológiai természetü, hiszen az a tény, hogy az etikát az emberi természethez kapcsolja, ezzel előfeltételezi ennek a természetnek az ismeretét. Tetézi még a problémát az a fontos kérdés is, hogy mindebbe hogyan illeszthető be a társadalom? Összegezve megállapítható, hogy az emberi természet fogalma

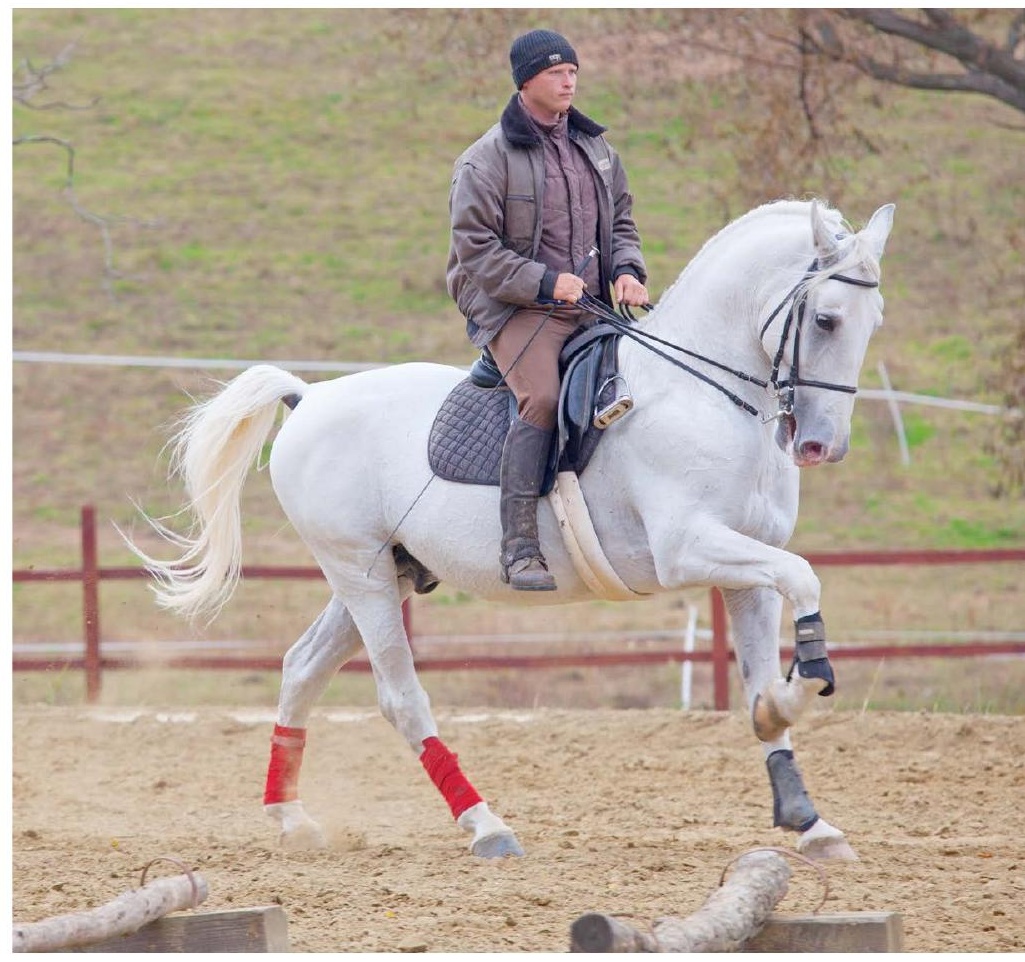

www.recreationcentral.eu 
igen enigmatikus, nehezen meghatározható, többértelmű fogalom. Egy olyan hasonlat, amely több eltérő jellegű elméleti álítás helyett állhat. Heller Ágnes az emberi természet fogalmát a fentiek miatt a conditio humana fogalmával váltja fel (http://mmi.elte.hu).

„Conditio humana a történetiség determinációját és öndeterminációját jelenti a történelmi hiátus körülményei között" (Heller; 1994).

A természettel való tudatos foglalkozás egy igazi csapatjáték kell, hogy legyen, társadalmi felelősségvállalás, melynek egy nagyon fontos eleme a természetvédelem.

A természetvédelem célja a tudományos és kulturális szempontból legjelentősebb természeti értékek természetes, vagy ahhoz közel álló állapotban és természetes változási folyamatban való megőrzése, fenntartása és bemutatása révén azok közkinccsé tétele.

A természetvédelem részletes célja:

- természeti értékek megőrzése, megóvása, fenntartása és a fennmaradásukhoz szükséges feltételek megteremtése;

- az élővilág évmilliók alatt kialakult génvagyonának, sokféleségének, mint újratermelődő természeti erőforrásnak és kincsnek is a jelen és jövő nemzedékek számára való megőrzése;

- a védett növény- és állatfajok viselkedésének, szaporodásának figyelemmel kísérése révén a természetes jelző (indikátor) szerep betöltése;

- A (tudományos) kutatások külső, szabadtéri feltételeinek biztosítása;

- a természetvédelem népszerüsítése által a társadalom természetet védő magatartásának kialakítása céljából nevelés, az oktatás, a képzés, a közművelődés és az ismeretterjesztés révén a tudatformálás elősegítése;

- a szabadidő minél nagyobb részben a természetben való eltöltésének elősegítése; az igényesebb pihenési formák lehetöségeinek megteremtése útján az életmód és az emberek közérzetének javítása, valamint a külföldröl hazánkba látogatókkal országunk természeti értékeinek megismertetése, ezáltal hazánk megszerettetése; az egészséges életre való nevelés; az üdülötelepek és azok környezetének védelme, azok esztétikus, tájba illö kialakítása és gondozása révén az üdülés kellemesebbé tétele, s ezzel a közízlés formálása;

- a szanatóriumok, kórházak, gyógyhelyek és egyéb egészségügyi intézmények természeti környezetének megóvása, a gyógyforrások védelme és gyógybarlangok kijelölése útján a gyógyítás feltételeinek megőrzése, megteremtése vagy javítása;

- a természet látványa révén a közvetlen, a természetvédelem tárgyairól készülö fényképek és filmek, festmények, szobrok, zenemúvek, irodalmi és egyéb alkotások létrehozása lehetőségeinek megteremtésével a múvészetek támogatása és a közvetett gyönyörködtetés;

- nagyobb kiterjedésü védett földterületeknek környezetvédelmi mintaterületekké való kifejlesztése által a környezetvédelmi tevékenység magasabb színvonalra emelése (Rakonczay; 2001).

A rekreáció szempontjából kiemelt jelentőségű a természetvédelem céljai között megtalálható két vastagon kiemelt cél megfogalmazása, mely a mozgásos és szellemi rekreáció jelentőségét is hangsúlyozza.

A természetre nyitott emberek maguk élvezik ki a természet nyújtotta lehetőségeket, kihasználva a közvetlen környezet adottságait, vagy élve a turizmus lehetőségével más rekreációs szokásokat is megismerhetnek, távolabbi vidékeken.

Vannak azonban azok az emberek, akik szintén a természet felé nyitottak, de azon belül a speciális látásmódjuknak, művészi hajlamaiknak köszönhetően a természet által ihletett alkotásokat is ké- szítenek. „A művészet nem a láthatót adja vissza, hanem láthatóvá tesz." (Paul Klee)

Ezen alkotások biztosítani tudják a természet jelenlétét a szürke mindennapokban is, kikapcsolódást nyújtva a közvetlen környezetében élőknek.

Milyen érdekes rekreációs halmozódás is előfordulhat abban az esetben, ha pl. a müvész szabadidejét töltötte a hegyekben, miközben megfestette az ott csodált környezetet, amit aztán egy belvárosi kiállitáson egy látogató szabadidejében megnéz, és gondolatban elrepíti magát a pörgős belvárosi forgatagból az árnyas erdők mélyére, ami neki relaxációval, szellemi feltöltődéssel párosul.

$$
\text { Irodalomjegyzék: }
$$

- Cseresznye Gyula: A természet és környezetvédelem fogalma. http://www.zoldmuzeum.hu/a-termeszet-es-kornyezetvedelemfogalma (Letöltve: 2014. 01. 11.)

- Szabadbölcsészet - Fogalomtár Etika szakosoknak. Emberi természet. (Heller Ágnes: Általános etika. 21-26. alapján) http://mmi. elte.hu/szabadbolcseszet/index.php?option=com_tanelem\&id_ tanelem $=452 \&$ tip $=0$

- Rakonczay Zoltán: Természetvédelem. Mezőgazdasági Szaktudás Kiadó, Budapest, p. 56-57. 2001. ISBN: 9789633562253

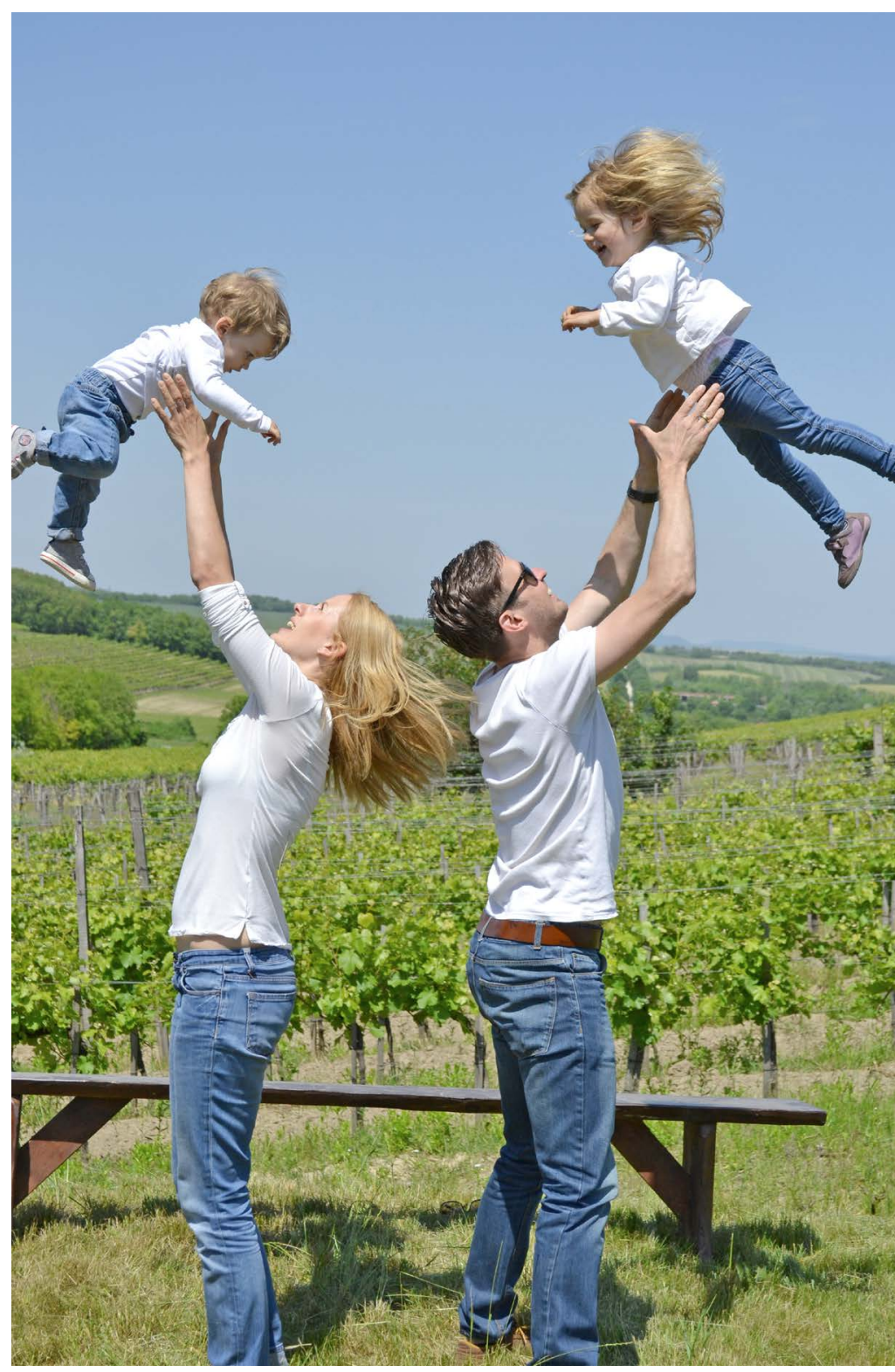

2016. TAVASZ 